\title{
Is Global Warming The Cause For The Dwindling European Eel Population?
}

\author{
Vincent van Ginneken* and Patrick Niemantsverdriet \\ Blue Green Technologies, Netherlands
}

Submission: March 25, 2017; Published: May 24, 2017

*Corresponding author: Vincent van Ginneken, Blue Green Technologies, Ginkelseweg 2, 6866 DZ Heelsum, Netherlands, Tel: 0638071180; Email: vvanginneken@hotmail.com

\begin{abstract}
The European eel has been dwindling since the eighties of the previous century. Animals exhibiting temperature dependent sex determination (TSD), including eels, are perhaps most vulnerable to a warming of the Earth as highly skewed sex ratios can result, potentially leading to population extinction resulting from decreased male recruitment. Here we report based on time series dating from 1930 of annual catch of male and female silver eels from eight sites that are open for glass eel influx around Lake Ijssel, the Netherlands. We observed that the sex ratio was skewed gradually towards females. The significant female-skewness of the sex ratio validated that the population of European eels at these sites has declined to a very low level since the 1930s. From several field and laboratory studies we have indications that Environmental Sex Determination (ESD) is prevalent and that the temperature determines the ultimate sex of the eel. Comprehensive studies of the sexual differences of eels are important for conservation programs.
\end{abstract}

Keywords: European eel; Anguilla anguilla; Global warming; Spawners; Dwindling population

\section{Introduction}

Since the mid-nineteenth century, a notable increase $(0.6-$ $0.8^{\circ} \mathrm{C}$ ) in the Earth's mean surface temperature has been documented and is continuing at an accelerated rate [1,2]. The European (Anguilla anguilla L.) an eel species of the moderate temperature zones- has been dwindling since the eighties of the previous centuries [3] and is an endangered species [4]. Possible causes for its decline were investigated in previous research manuscripts to mention

a. Swimbladder parasite Anguillicola crassus [5].

b. Eel viruses with mainly the EVEX virus in Europe $[6,7]$ and PCBs [8].

Recently we have collected historical time series of fishermen around lake IJssel in the Netherlands which show a large corresponds in shape (after log transformation) in terms of changing sex ration for migrating silver eels with the global warming graph. The question arises what determines the ultimate sex of European eel. Environmental sex determination (ESD) has been detected in many vertebrates including turtles [9], many reptiles [10] and certain fish species [11-13]. Similar to reptiles, the incubation temperature during early phases of development is capable to modify sex ratios in a large number of fish species. This phenomenon, known as thermolabile sex determination
(TSD) was reported for an increasing number of fish species [14] were in most cases females were found at low temperatures and males at high temperatures [15]. However, recently in the review of [16] the occurrence of TSD in fishes has to a large extent been taken into consideration. Many studies regarding the influence of temperature on the final sex ratios have been focused on the expression and activity of gonadal aromatase, the enzyme involved in the conversion of androgens into estrogens and encoded by the cyp19a1a gene [17]. In this regard, teleost fish, may be due to a whole genome duplication event, produce another aromatase enzyme, commonly named brain aromatase, encoded by the cyp19a1b gene [17]. However, the mechanism whereby temperature can induce the development of a testis or an ovary in fishes still remains elusive.

\section{Material and Methods}

In this letter a historical dataset going back to the thirties of the previous century of caught migrating silver eel split up to sex at eight locations around lake Ijssel, the Netherlands is discussed in relation to global warming. Local fishermen and trading places around the lake Ijssel with open retractable glass eels were visited which meet the criterion they didn't had any glass eel restocking program. This resulted in eight convenient locations around lake IJssel, the Netherlands (Figure 1). From 
the archives and records from local fishermen the number of caught migrating silver eels (in kilograms) were recorded by year and split up to the sex. Criterion for sex differences were the weight of the animals. Eels in excess of 200 grams were referred to as females. Some records even dated from the fathers and grandfathers of these fishermen. The eight datasets were put chronologically in Excell and log transformed. The resulted log transformed graph of Figure 1 is depicted in Figure 2 and can be compared with Figure 3. The latter was composed of time series of annual values of global mean temperature anomalies from the National Centers for Environmental Information: National Oceanic and Atmospheric Administration [18].

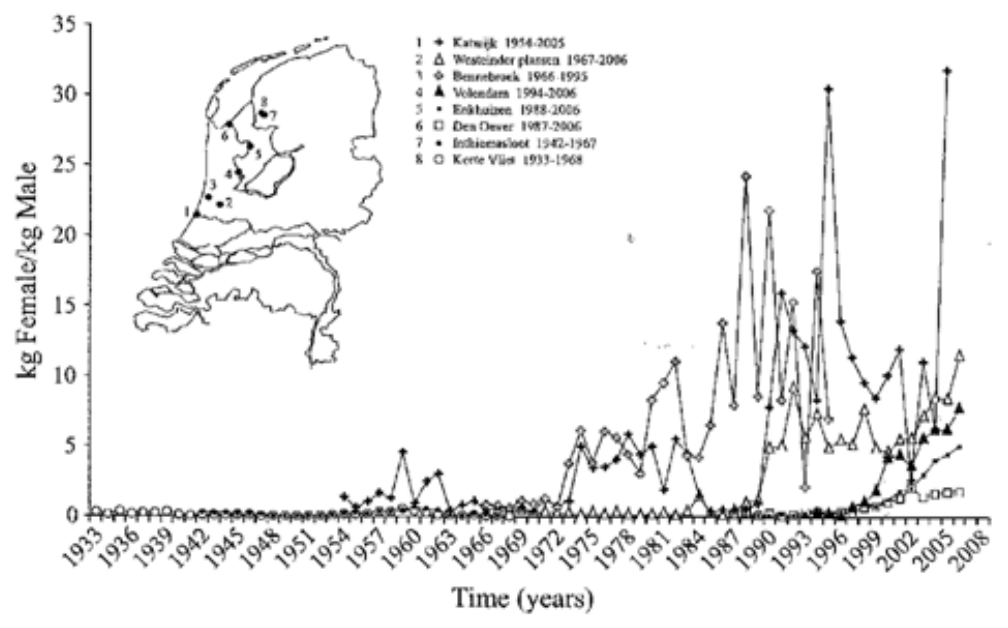

Figure 1: Historical time series dating from 1930 of annual catch of male and female silver eels from several sites that are open for glass eel influx in the Netherlands.

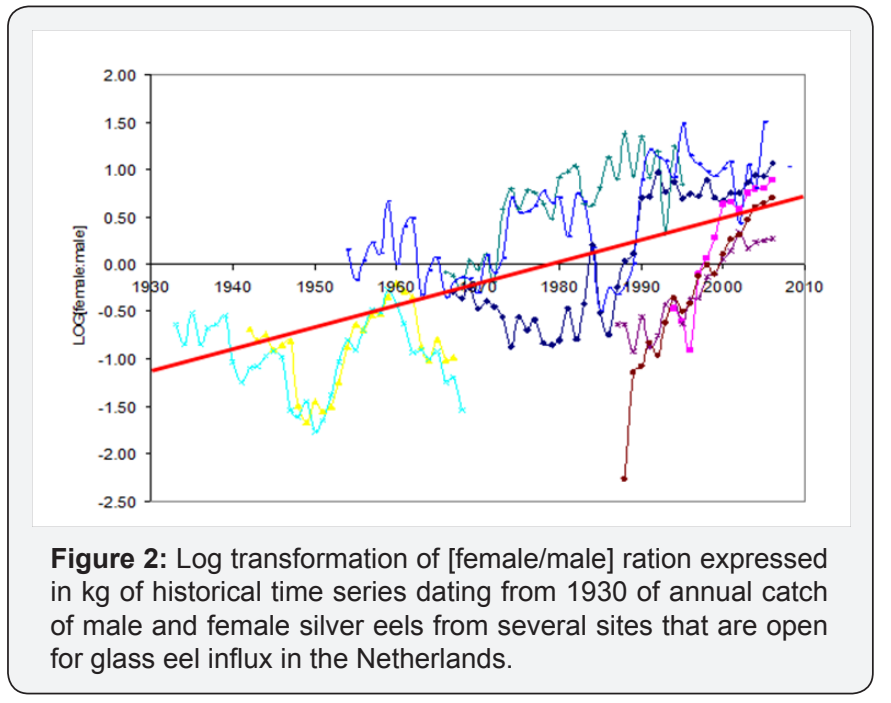

\section{Results and Discussion}

This study gives supportive evidence, that the effects of global warming will have enormous impacts on the European eel (Anguilla anguilla). In the present investigation, we observed in data series of annual catch data starting from the eighties of the previous century until 2006 in lake IJssel, the Netherlands, that the amount of kg caught eels remained more or less the same but that the sex ratio was skewed towards females. We observed a decrease of caught males with $50 \%$ and a threefold increase of caught females. This trend corresponds to the dramatic

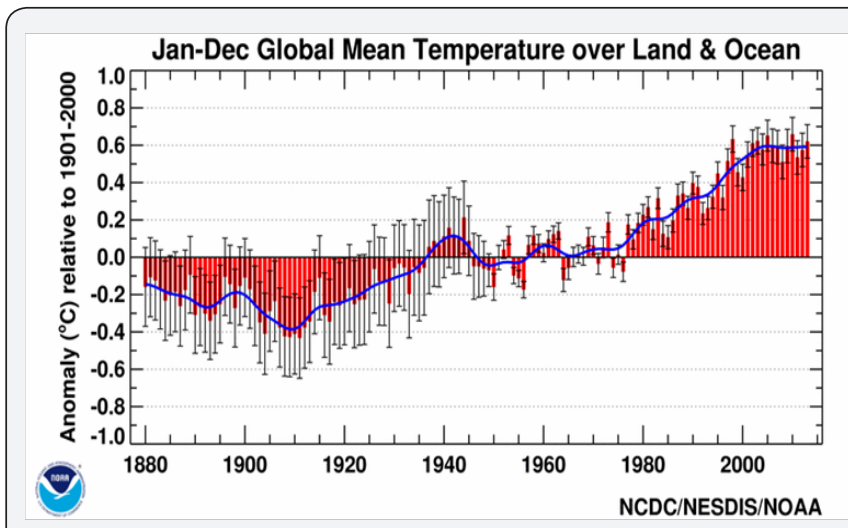

Figure 3: Time series of annual values of global mean temperature anomalies from the National Centers for Environmental Information: National Oceanic and Atmospheric Administration [18].

decline of glass eel influx at Den Oever, the Netherlands [19] over the last 30 years. So, it is likely that the reduced influx is the primary cause for the change in sex ratio. In fact the three eel species from the temperature moderate zones: The European eel (A.anguilla), the Japanese eel (A.japonica) and the American eel (A.rostrata) can be affected by global warming. The rate of global warming far exceeds the abilities of these fishes to adapt naturally to such dramatic environmental changes and as such these eels are endangered fish species [20]. As far as we know there are not many comparable long-term data sets available 
that have measured the sex ratio in the eel population in a few years and linked to TSD or global warming. In Europe solely one long-term records (1781-2013) of European eel (Anguilla anguilla L.) production in the Comacchio Lagoon (Italy) was published in relation to evaluation of local and global factors as causes of the population collapse but no correlation was made with global warming [21].

However, in another study performed over a time period of 5 year (1998-2002) in the Kaoping River in Taiwan a significant female-skewness of the sex ratio [22] was also observed which gave supportive evidence for our results and interpretation as presented in our study. Many investigations at sex differentiation of eels had the wrong assumption that food supply or stocking density were the major determinants for the ultimate sex of glass eel (reviewed: [23]). Their conclusions were that growth and sex ration are linked processes during eel development, with growth seeming to be sex dependant rather than being influenced by the density conditions in which glass eels are maintained [23]. The basic problem with sex differentiation studies was that they must take place over several years, and selective mortality and fluctuating husbandry conditions may also affect and bias the end result [24]. In addition, in eel farms at high temperatures of around $24-26^{\circ} \mathrm{C}$ most glass eels become male [24]. It is therefore logical that, until recently, first sex differentiation was attributed to food supply or density by these observations and secondly, that the theory of TSD for eel was put on the wrong track by observations in eel farms giving rise to skewed sex rations towards males. Fortunately, very recently a study was published showing a molecular gene for sexual dimorphism in eel [25] which makes the presented results of this study more plausible. Climate change effects on the sex ratio of animal species have solely until at present been inferred for the loggerhead turtle, a species with also TSD [9]. This is the first study where for a fish species the effects of global warming on skewed sex ration are presented. In addition to our awareness this is the first study with long term historical datasets for the European eel for which so clearly a correlation is made between sex differentiation and global warming. With declining European eel populations of $90-99 \%$ [4] and an overall reduced glass eel influx in Europe [19] this strategy to invest in females with a high fecundity "the fecundity advantage model" (reviewed: [26]) can be a natural mechanism to safeguard this species and be a final attempt to prevent extinction of this endangered fish species.

In addition, European eels exhibit a sexual size dimorphism model where females in the Netherlands can reach up to 1 meter long [27] and males have solely a length between 30 and 40 centimeters [28]. This difference in size has consequences for their points of departure (because both sexes swim at 0.5 body length per second) [29], where the males leave the European costs 2-3 months earlier (August-September), while the females departure is October-November, in order to arrive at the same time in the Sargasso Sea to spawn collectively and simultaneously [3]. For most evolutionary models with fish, the females are most important because of their higher fecundity which is called the "fecundity advantage" model, critically reviewed by [26]. But taking into consideration its life cyclewith spawning grounds $6000 \mathrm{~km}$ far away in the Sargasso Sea $[3,28]$ in combination with global warming $[1,2]$ contribution of both sexes is equally important. Therefore restocking programs should take the "equal sex theory" into consideration to balance the sex ratio of the wild population in this way contributing to the spawning stock of the European eel [30].

\section{References}

1. Levitus S, Antonov JI, Wang JL, Delworth TL, Dixon KW, et al. (2001) Anthropogenic warming of Earth's climate system. Science 292(5515): 267-270.

2. Walther GR, Post E, Convey P, Menzel A, Parmesan C, et al. (2002) Ecological responses to recent climate change. Nature 416(6879): 389-395.

3. van Ginneken V, Maes G (2005) The European eel (Anguilla anguilla, Linnaeus), its lifecycle, evolution and reproduction: a literature review. Reviews in Fish and Fisheries 15(4): 367-398.

4. Stone R (2003) Freshwater eels are slip-sliding away. Science 302(5643): 221-222.

5. Palstra AP, Heppener DFM, van Ginneken VJT, Székely C, van den Thillart, et al. (2007) Swimming performance of silver eels is severely impaired by the swim-bladder parasite Anguillicola crassus. Marine Biology and Ecology 352(1): 244-256.

6. van Ginneken V, Haenen 0 , Coldenhoff K, Willemze R, Antonissen E, et al. (2004) Presence of eel viruses in eel species from various geographic regions. Bull Eur Ass Fish Path 24(5): 270-274.

7. van Ginneken V, Ballieux B, Willemze R, Coldenhoff K, Lentjes E, et al. (2005) Hematology patterns of migrating European eels and the role of EVEX virus. Comp Biochem Physiol C Toxicol Pharmacol 140(1): 97102.

8. van Ginneken V, Palstra A, Leonards P, Nieveen M, van den Berg H, et al. (2009) PCBs and the energy cost of migration in the European silver eel (Anguilla anguilla L.). Aquat Toxicol 92(4): 213-220.

9. Sari F, Kaska Y (2016) Histochemical and immunohistochemical studies of the gonads and paramesonephric ducts of male and female hatchlings of loggerhead sea turtles (Caretta caretta). Biotech Histochem 91(6): 428-437.

10. Janzen FJ, Paukstis GL (1991) Environmental Sex Determination in Reptiles: Ecology, Evolution, and Experimental design. Q Rev Biol 66(2): 149-179.

11. Baroiller JF, Guigen Y, Fostier A (1999) Endocrine and environmental aspects of sex differentiation in fish. Cellular and Molecular Life Sciences CMLS 55(6): 910-931.

12. Baroiller JF, D'Cotta H (2001) Environment and sex determination in farmed fish. Comparative Biochemistry and Physiology Part C: Toxicology \& Pharmacology 130(4): 399-409.

13. Devlin RH, Nagahama Y (2002) Sex determination and sex differentiation in fish: an overview of genetic, physiological, and environmental influences. Aquaculture 208(3-4): 191-364.

14. Conover DO (2004) Temperature-dependent sex determination in fishes. In: Valenzuela N, Lance V (Eds.), Temperature-dependent sex determination in vertebrates. Smithsonian Books, Washington, USA, pp. $11-20$

15. Braun McNeill J, Avens L, Goodman HA, Goshe LR, Harms CA, et al. (2016) Female-Bias in a Long-Term Study of a Species with 
Temperature-Dependent Sex Determination: Monitoring Sex Ratios for Climate Change Research. PLoS ONE 11(8): e0160911.

16. Ospina-ÁN, Piferrer F (2008) Temperature-Dependent Sex Determination in Fish Revisited: Prevalence, a Single Sex Ratio Response Pattern, and Possible Effects of Climate Change. PLoS ONE 3(7): e2837.

17. Blazquez M, Somoza GM (2010) Fish with thermolabile sex determination (TSD) as models to study brain sex differentiation. Gen Comp Endocrinol 166(3): 470-477.

18. NOAA (2015) National Centers for Environmental Information, State of the Climate: (National Oceanic and Atmospheric Administration). Global Analysis for Annual 2014. USA.

19. Dekker W (2004) Slipping through our hands. Population dynamics of the European eel. PhD-Thesis University of Amsterdam, Netherlands, pp. 186

20. Stone R (2003) Freshwater eels are slip-sliding away. Science 302(5643): 221-222.

21. Aschonitis V, Castaldelli G, Lanzoni M, Rossi R, Kennedy C, et al. (2016) Long-term records (1781-2013) of European eel (Anguilla anguilla L.) production in the Comacchio Lagoon (Italy): evaluation of local and global factors as causes of the population collapse. Aquatic Conserv: Mar Freshw Ecosyst 27(2): 502-520.

22. Han YS, Tzeng WN (2006) Use of the Sex Ratio as a means of resource assessment for the Japanese Eel Anguilla japonica: A case study in the Kaoping River, Taiwan. Zoological Studies 45(2): 255-263.
23. Huertas M, Cerdà J (2006) Stocking density at early developmental stages affects growth and sex ratio in the European eel (Anguilla anguilla). Biological Bulletin 211(3): 286-296.

24. van Ginneken VJT, Razzaq W, Masood Z, van den Thillart G (2016) Precocious silvering of Farmed eels with Special Reference to their Evidence for Genotypic Sex Determination. J Appl Environm Biol Sci 6(7): 139-148.

25. Geffroy B, Guilbaud F, Amilhat E, Beaulaton L, Vignon M, et al. (2016) Sexually dimorphic gene expressions in eels: useful markers for early sex assessment in a conservation context. Sci Rep 6: 34041.

26. Shine R (1988) The Evolution of large body size in females: a critique of Darwin's "Fecundity Advantage" model. The American Naturalist 131(1): 124-131.

27. van Ginneken V, van den Thillart G (2000) Eel fat stores are enough to reach the Sargsso. Nature 403(6766): 156-157.

28. van Ginneken V, Saddozai (2016) Precocious silvering of Farmed eels in relation to their Physiological Aspects. J Appl Environm Biol Sci 6(7): 30-37.

29. van Ginneken V, Antonissen E, Müller UK, Booms R, Eding E, et al. (2005) Eel migration to the Sargasso: remarkably high swimming efficiency and low energy costs. J Exp Biology 208(Pt 7): 1329-1335.

30. Chu YW, Han YS, Wang CH, You CF, Tzeng WN (2006) The sex-ratio reversal of the Japanese eel Anguilla japonica in the Kaoping River of Taiwan: the effect of cultured eels and its implication. Aquaculture 261(4): 1230-1238.

\section{Your next submission with Juniper Publishers will reach you the below assets}

- Quality Editorial service

- Swift Peer Review

- Reprints availability

- E-prints Service

- Manuscript Podcast for convenient understanding

- Global attainment for your research

- Manuscript accessibility in different formats

( Pdf, E-pub, Full Text, Audio)

- Unceasing customer service

Track the below URL for one-step submission https://juniperpublishers.com/online-submission.php 